\title{
Some negative contents portrayed in English song lyrics
}

\author{
${ }^{1}$ Liliek Soepriatmadji*, ${ }^{1}$ Katharina Rustipa \\ ${ }^{1}$ English Literature Study Program, Faculty of Language and Cultural Studies, \\ Universitas Stikubank, Indonesia, \\ *Corresponding Author \\ Email: lilieksoepriatmadji@edu.unisbank.ac.id
}

\begin{abstract}
Some song lyrics may have been banned or rescheduled for their radio and television broadcasts. Those song lyrics were claimed to propagandize negative contents. Recently West Java Broadcasting Commission has regulated the broadcast of 17 western songs for the prejudice of negative contents. Based on semantic analysis of those song lyrics, the authors finally found out that they qualitatively describe lust, profanity, drug and alcohol abuse, etc. through periphrasis, simile, litotes, meiosis, and other speech figures. Clauses were selected to deliver the figures of speech of the lyrics sung by mostly male singers and the male-female duets in pop and $r$ and $b$ music genres.
\end{abstract}

Keywords: song lyrics; negative content; speech figure; music genre

Received: $\quad$ Revised: Accepted: Published:

13 November $2019 \quad 6$ February $2020 \quad 9$ February $2020 \quad 29$ February 2020

\section{INTRODUCTION}

Song lyrics are considered as parts of creative literary work performed with various music genres. Those who enjoy song lyrics with different music genres vary in age, education, ethnicity, culture, and country. Their nature is universal that people who enjoy song lyrics and music no matter of the genre may come from across nations, cultures, and countries. The main goal of such creative literary work is to entertain the song lyric writers themselves, the singers, and the listeners. However, differences in ideology and socio-religious norm among the song lyric writers, singers, and listeners pertaining to the content may create anxiety.

Such an anxiety has so far triggered broadcast banning or broadcast banning during the day. Some countries have banned some song lyrics for radio and television broadcasts. The song lyric entitled Baby It's Cold Outside, which was written by Frank Loesser in 1944 was banned for radio broadcasts in the United States (Jones, 2018). Malaysia has banned Luis Fonsi's song lyric, Despacito, for the state radio and television broadcasts even at its popularity in 2017 (Allegri, 2019). K-pop song lyrics of South Korea was also reported to be banned in North Korea (Koreaboo, 2018). Such banning also 
Soepriatmadji, L., \& Rustipa, K. (2020). Some negative contents portrayed in English song lyrics. EduLite: Journal of English Education, Literature, and Culture, 5 (1), 148-158.

occurred in Indonesia. The Local Indonesian Broadcasting Commission (KPID) of West Java has recently issued an official letter number 480/215/IS/KPIDJABAR/II/2019 to officially ban 17 English songs and clips for radio and television broadcasts during the day. Those songs can only be broadcast after 10 p.m. to 3 a.m. (Ramdhani, 2019; Samudro, 2019).

It is not the music genre which is banned but the content of the song lyric which makes the government ban the song lyric for radio and television broadcasts. In general, the content is potential for lust, violence and vulgar attitude and verbal behavior for the listeners (Mutegi, Bannister, \& Nichols, 2014). Even song lyric may be potential for political sentiment such as K-pop for North Korea (Koreaboo, 2018) and Genjer-genjer in the new order of Indonesia (Susilo, 2019). Because of such a potential, the government banned the 17 song lyrics for radio and television broadcasts (Ramdhani, 2019).

Experts claim that there are many song lyrics which expose lust, vulgar free sex, verbal violence, misogyny, and hatred (Kusumaningsih, Santosa, \& Subroto, 2018). It is also admitted that there is a significant change in the content of song lyrics from love to free sexual lust (Madanikia \& Bartholomew, 2014). There are 49 hip-hop song lyrics which expose negative contents (Mutegi et al., 2014). Those negative content or exposure of the song lyrics are believed to be of significant influences to aggressive attitude, feeling, physical and verbal behavior for the song lovers (Frisby, 2016) (Anderson, Carnagey, \& Eubanks, 2003).

For Bruno Mars, the singer of That's What I Like and Versace On The Floor, two of the 17 songs being banned for radio and television broadcasts during the day claims that they do not contain vulgar free sex (Ramadhani, 2019). In his twitter account (@BrunoMar), he said Dear Indonesia, I gave u the wholesome hits "Nothin On You," "Just The Way You Are," \& "Treasure." Don't lump me in with that sexual deviant. Some Indonesian musicians, people working in music industries, and Indonesian music lovers regretted the banning of the 17 English songs for radio and television broadcasts (Setiawan, 2019). West Java KPID, on the other hand, thought in a different way. Those 17 song lyrics, including That's What I Like and Versace On The Floor contain and expose free sexual lust, vulgar sexual activities, and verbal violence (Ramadhani, 2019) (Samudro, 2019). The fact that West Java KPID has officially issued a letter for banning the 17 song lyrics for radio and television broadcasts during the day due to negative contents.

This study is aimed at portraying the negative content or exposure of those 17 English song lyrics which may be potential to trigger risky attitude, physical and verbal behavior for the lovers. Specifically, it is aimed to (1) describe the variant of negative content or exposure of the 17 song lyrics being banned by West Java KPID for radio and television broadcasts during the day; (2) elaborate how the negative exposure was portrayed in the song lyrics; (3) explain if the song lyrics containing negative exposure are equally sung by male and female singers; (4) describe which genre of the 17 songs contain negative exposure.

\section{Song lyrics as creative literary work}


Song lyrics have been so far capable of hypnotizing their lovers, who were noticed to be from different ages and nations for the purpose of entertaining, teaching, therapeutic healing, religious enchanting, meditating, motivating patriotism, positioning racial and cultural identity (Monson, 2000). A song lyric is usually presented with a melody and emphasizes almost all aspects of human life to be enjoyed in leisure time. Therefore, song lyrics can be studied from different viewpoints, such as their structure, lexical elements, themes, grammatical elements, social functions, and their contents. West Java KPID and West Java Stakeholders have so far discussed the banning of or rescheduling the radio and television broadcasts of the 17 songs which they thought and analyzed to expose negative contents.

Those songs are listed as follows:

1. Dusk Till Dawn (Zayn Malik)

2. Sangria Wine (Camila Cabello ft Pharrell W)

3. Mr. Brightside (The Killers)

4. Let Me (Zayn Malik)

5. Love Me Harder (Ariana Grande)

6. Plot Twist (Marc E. Bassy)

7. Shape of You (Ed Sheeran)

8. Overdose (Chris Brown ft Agnez Mo)

9. Makes Me Wonder (Maroon 5)

10. That's What I Like (Bruno Mars)

11. Fuck It I Don't Want You Back (Eamon)

12. Bad Things (Camila Cabello ft Machine)

13. Versace on the Floor (Bruno Mars)

14. Midsummer Madness (88rising)

15. Wild Thoughts (DJ Khaled ft Rihanna)

16. Till It Hurts (Yellow Claw)

17. Your Song (Rita Ora).

(Ramdhani, 2019)

\section{Music lovers}

Listening to music has become a general activity of young people in their leisure time. It was reported that American young people, at the age of 8 to 18 , spend their time listening to music for 2 hour 31 minutes (Rideout, Foehr, \& Roberts, 2010). The length of time they need for listening music increases in line with the increase of their age. A Swedish digital music industry Spotify has proved that its music has been played for 1,165 billion minutes during the first five months of operation. Male music lovers (68\%) as compared to female music lovers (32\%) are noticed to enjoy music even when they are in the bathroom (Suwanto, 2016).

\section{The content of song lyric}

The lyrics of 50 Indonesian songs being popular in 1998 to 2017 expose vulgar and sexual expressions (Kusumaningsih et al., 2018). Pop and hip hop or rap are the music genres among others which are very popular to young people. Unfortunately, they very frequently adopt profanity, violence, misogyny (Frisby, 2016). Hip hop/rap is considered as a music genre which is related to pornography endorsing lust and ideological and behavioral violence (Lynxwiler 
Soepriatmadji, L., \& Rustipa, K. (2020). Some negative contents portrayed in English song lyrics. EduLite: Journal of English Education, Literature, and Culture, 5 (1), 148-158.

$\&$ Gay, 2000). The expressions used tend to communicate profanity, violence, misogyny.

\section{The danger of negative content in song lyrics}

There are many researchers who claim that hip hop exposes lust, profanity, and violence in the song lyrics which are potential to ruin and spoil the verbal behavior and attitude of young people (Rudman, L. \& Lee, 2002). Similar opinion also claims hip hop or rap tend to expose women as objects which are often underestimated in word such as "bitch, ho, and skeezer" (Powell, 1991). Those taboos may be potential for young people to accept violence, negative behaviors, and aggressiveness (Thompson, Geeves, \& Olsen, 2018; Johnson, Adams, Ashburn, \& Reed, 1995).

George Michael once shocked the world music industry by releasing a single entitled 'I Want Your Sex' in June 1997. Many Indonesian parents broke the cassette to avoid their children being influenced with immoral song lyric. The single exposes sexual slangs, and that sex is free to enjoy (Moernantyo, 2015).

The powerful influence of song lyrics in arousing lust has been explained by Dr. Brian A Primack, a researcher from the medical faculty of Pittsburgh University, AS. Song lyrics exposing lust may stimulate human brain to develop sexual responses (Nauert, 2018). Such lyrics also potentially hypnotize the listeners to continue doing sexual activities. The song lyric may accompany the sexual activity. For young people such idea may trigger free sexual practices because they are stimulated to exercise themselves with the joy of intercourse. One third of 711 volunteers at the age of 14 committed to practice free sex after being exposed to porn and sexual songs for 14 hours. Even those young people may have been excited with free sex practice more than once (Nauert, 2018).

\section{METHOD}

The main purpose of the research is to qualitatively elaborate the meaning and social construction created in the data as to the understanding of (1) the negative contents, (2) the manners in elaborating the negative contents, (3) the gender role in communicating the negative contents, (4) the music genres which are supposed to contain negatives contents. Therefore, the research follows interpretive paradigm through semantic analysis. The lyrics were coded based on (1) the negative content, such as profanity, violence, misogyny, racists, lust, drug use, or alcohol use; (2) the linguistic units and the speech figures used to communicate the negative contents, (3) the gender roles, and (4) the music genres.

\section{Samples}

This research used total sampling because the data were only seventeen (17) songs, which were banned by the West Java KPID for radio and television broadcasts.

\section{Procedures}


The data were gathered by visiting web sites which provide the song lyrics. After downloading them the lyrics were segmented in their unit of analysis and labelled for further coding with respect to content variants, speech figures, linguistic units, gender roles, and music genres.

\section{Data analysis}

The data were analysed by (1) elaborating the descriptions of the contents of lyrics with respect to their negative labels, (2) elaborating the speech figures which expose the negative contents (3) describing the linguistic units, gender role, and music genres which expose the negative contents.

\section{RESULTS AND DISCUSSION Negative contents of the song lyrics}

Negative contents being propagandized in the 17 songs having been banned for radio and television broadcasts during the day vary in some way. In general they expose lust, profanity, violence, misogyny drug and alcohol abuse, and racist. Figure 1 lets everyone know that lust (62\%) and profanity $(20 \%)$ are propagandized mostly than the other negative variants. Parents have to pay a careful attention to the song lyrics their children like to listen. As it is admitted worldwide that Indonesians are mostly Islamic religious, parents may involve themselves in the discussion of their children's interest in western songs. Young people must be aware that song lyrics exposing negative contents truly violate the social values, norms of Islam, and their way of life.

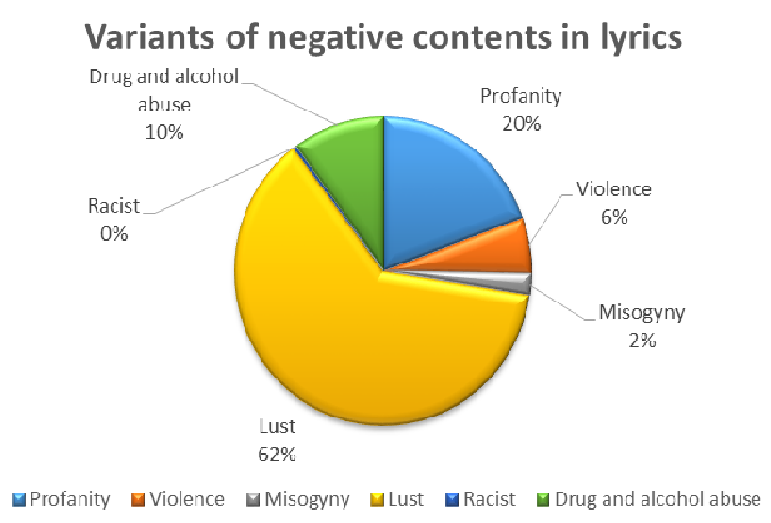

Figure 1. Variants of negative contents in lyrics

Almost all the song lyrics being investigated expose lust. Figure 2 indicates that the songs which significantly propagandize lust are those entitled: "Dusk Till Dawn" "Overdose" "Plot Twist" "Versace on the Floor" "Love Me Harder" "Till It Hurts" "Mr. Brightside."

"So do your zip", "Let's make love", "We will roll down the rapids" are some of the lyrics of the song entitled "Dusk Till Dawn" which propagandize lust. "Girl, your sex is a drug", "Every time I do you baby girl, I overdose" are some lyrics of "Overdose" which expose lust. Similarly, in "Till It Hurts," the lyrics "Hold me tight, read my lips", "Lay me down, blow my mind", "Make my 
Soepriatmadji, L., \& Rustipa, K. (2020). Some negative contents portrayed in English song lyrics. EduLite: Journal of English Education, Literature, and Culture, 5 (1), 148-158.

body burn" expose lust. Those lust propaganda may penetrate and stimulate the brains of the song lovers to exercise free sex (Nauert, 2018).

Other lyrics also expose the propaganda of drug and alcohol abuse, such as in "Sangria Wine." This song exposes drug and alcohol abuse as many as 26 clauses of the song lyrics, as in the lyrics "She do the sangria wine (woo)", "Sip it, sip it, I'll bet that you'll blush", "Now moving side to side (woo), now front and behind (uh-huh)." Those lyrics may stimulate the brains of the song lovers or listeners to try to sip or even drink wine and may excite them to experience to be drunk. "Sangria Wine" is not the only song which promotes and exposes the propaganda of drug and alcohol abuse. "Let Me" sung by Zayn Malik, "Shape of You" by Ed Sheeran, "Makes Me Wonder" by Maroon 5, and "Bad Things" by Camila Cabello ft Machine also do the same thing. Further, see figure 2. Songs which expose negative contents.

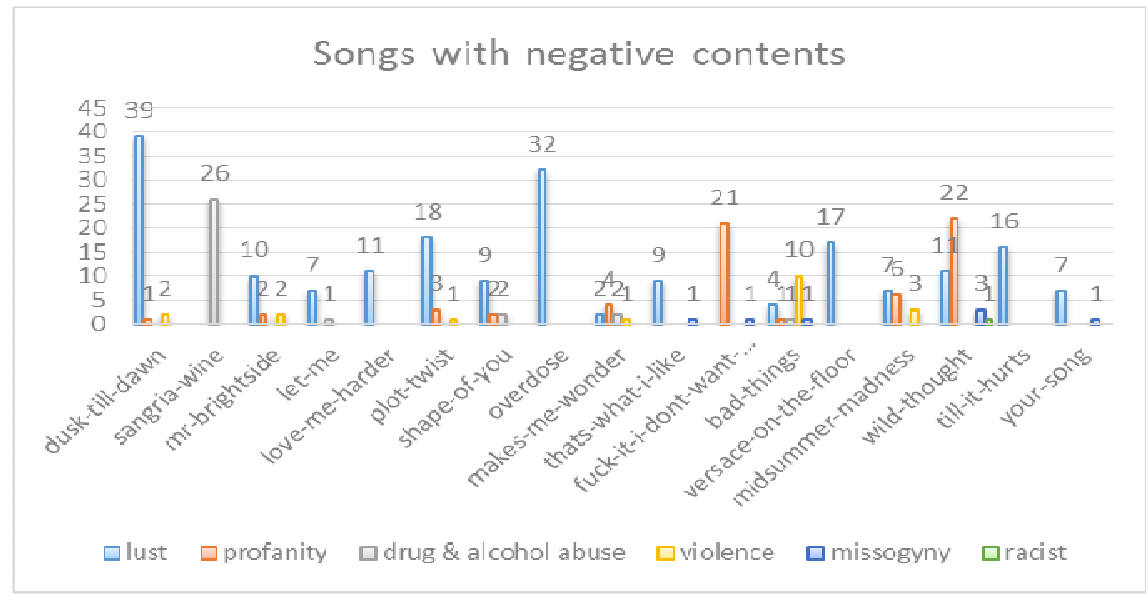

Figure 2. Songs which expose negative contents

The propaganda of profanity is exposed in 9 songs, 2 of which significantly communicate profanity. They are "Fuck It I Don't Want You Back" sung by Eamon which propagandizes profanity as many as 21 out of its 55 clauses; and "Wild Thoughts" sung by DJ Khaled ft Rihanna which exposes as many as 22 out of its 60 clauses. The words "fuck" and "shit" in the lyrics "Fuck what I said it don't mean shit now", and "Keep this shit from me, yeah" are profanity, therefore, should be avoided by civilized society members. Such profanity is believed to stimulate the brain of the song lovers to exercise its use in their utterances.

The propaganda of violence, such as the "wild" and "scratchin" are exposed in the lyrics "And we're both wild" and "Nails scratchin' my back tatt." There are 6 different songs which insignificantly expose such propaganda. However, violence in song lyrics may stimulate the song lovers as they listen to the songs. Similar case may also happen to misogyny and racist. The data indicate that there are 5 songs exposing misogyny, such as the word "fleeka", "mamacita" "bitch", "vixen" in "You can be my fleeka", "Girl, I'll be a fleeko, mamacita", "Ya burnt bitch, I heard the story", "You're my pretty little vixen". The propaganda of racist is found in "White girl wasted on that brown liquor," one clause in "Wild Thoughts" song lyric sung by DJ Khaled ft Rihanna. 


\section{Speech figures exposing negative contents in lyrics}

There are several speech figures used to communicate the negative contents of the 17 songs being investigated. Figure 3 displays that negative contents tend to be exposed in Periphrasis (102 times) in all the songs. This may mean that the negative contents are delivered in circumlocutions, clauses which express or describe the quality of a substance. "Dusk Till Dawn" may use such a speech figure in 29 clauses. "Sangria Wine," on the other hand, exposes negative contents in periphrasis as many as 26 clauses. For examples, the circumlocution "Let's make love" in "Let's make love tonight" is used to describe an appeal for lust. The circumlocution "do sangria wine" in "She do the sangria wine" is used to describe the propaganda alcohol abuse.

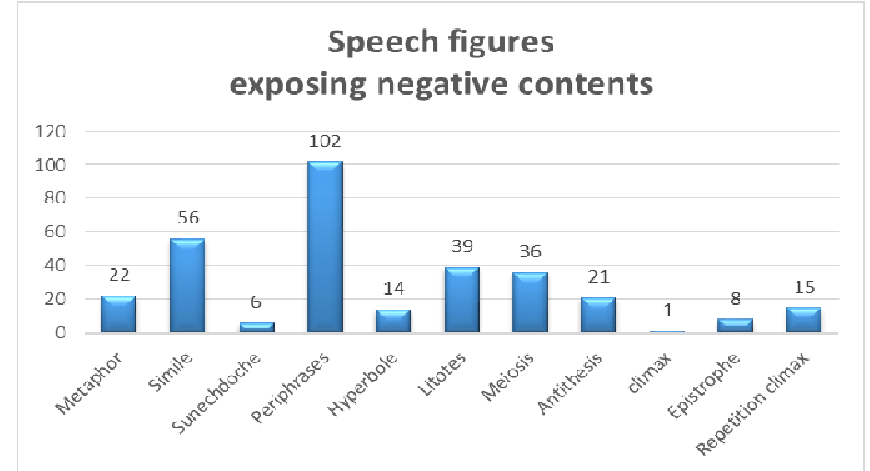

Figure 3 Speech figures exposing negative contents in lyrics

Simile is used as many as 56 times. This speech figure is to expose a negative content in an explicit comparison of two unlike things, for example, in "Overdose's" lyric "Girl, your sex is a drug," The word "sex" is explicitly different from the word "drug," but both are compared in order to propagandize lust.

Negative contents are also exposed in Litotes, as many as 39 times to indicate deliberate understatements. This speech figure is found in "Fuck It I Don't Want You Back" as many as 15 clauses, and in "Midsummer Madness" as many as 11 clauses. The word "fuck" in "Fuck the presents might as well throw em out," is an example of profanity, which is meant to deliberately show understatement in the word following it. Similarly, "fucked up" in "You were fucked up," is meant to expose profanity in an understatement towards the interlocutor.

Meiosis is used in the song lyrics to communicate lust as many as 36 times. This speech figure is meant to describe something disproportionately greater than the term implies. Thus, "a taste of your lips" in "I only wanted a taste of your lips." one of the lyrics in "Plot Twist" song may imply the want of more than just the taste of the lips. Similar case may also occur to the word "love" in one of "Till It Hurts" song lyrics "Like you love me tonight" which does not per se talk about the feeling of love, rather an appeal of lust.

Metaphor is also used to expose the negative contents of the song lyrics. This speech figure is used as many as 22 times to refer to one thing but which implies another thing. The lyrics of "Dusk Till Dawn" song demonstrating such use of metaphor is found in "So do your zip." Here "do you zip" does not only relate to the zip but could mean undress, which is the propaganda of lust. 
Soepriatmadji, L., \& Rustipa, K. (2020). Some negative contents portrayed in English song lyrics. EduLite: Journal of English Education, Literature, and Culture, 5 (1), 148-158.

Another speech figure used to expose negative contents in the song lyrics is Antithesis (21 times), which juxtaposes two contradictory ideas, as in "Bad Things" song lyrics "If you only knew the bad things I like," where "the bad things" and "I like" are in contradictory. Repetition climax, which is a repetition of anadiplosis at least three times and arranged so as to increase in importance each time is found in "Wild Thought" song lyrics as "Know you wanna see me nakey, nakey, naked" and "When I'm with you, all I get is wild, wild wild wild." Such a figure is used to propagandize lust and profanity as many as 15 times.

\section{Linguistic units propagandizing negative contents in lyrics}

The negative contents of the song lyrics are communicated mostly in clauses, such as "Let's just kiss 'til we're naked, baby." They are also communicated in phrases, such as "Now sangria wine" and in words such as "Wild, wild, wild." The idea of selecting clauses as the linguistic units that expose negative contents may be due to the reason that clause is more contextual than phrase or word.

LINGUISTIC UNITS TO COMMUNICATE NEGATIVE CONTENTS

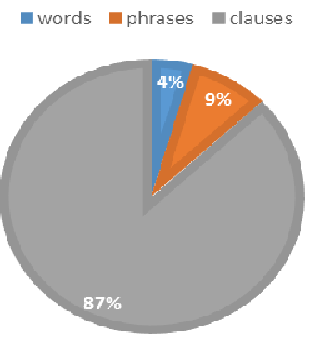

Figure 4: Linguistic units which communicate negative contents

\section{Genres and singers promoting negative contents in lyrics}

Even if it is not meant to generalize, the data indicate that the negative contents are exposed in pop, hip-hop, rhythm and blues, and dance music genres. See figure 5. Music genres expose negative contents. Parents, therefore, cannot be prejudiced to a certain music genre. Learning the content of the song lyrics and being with children in their interest in music would be wisely effective in helping children select their songs for their leisure time.

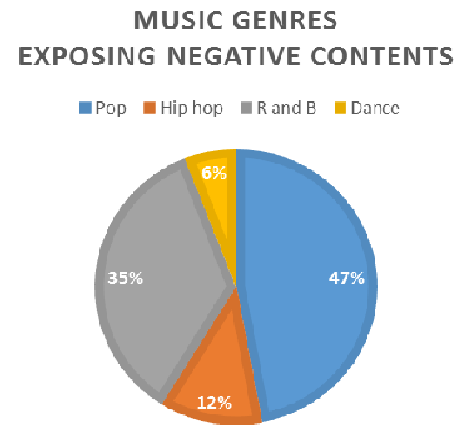

Figure 5: Music genres which expose negative contents 
The data also explain that male singers (47\%), such as Ed Sheeran in "Shape of you" and male-female duets (41\%), such as Chris Brown and Agnez Mo in "Overdose", promote song lyrics which propagandize negative contents. Though insignificantly, female singers also promote negative contents in their song lyrics. However, this may mean that people cannot just judge male or female singers to be in support of the bad side of the song lyrics. Parents may help their children explain the life records of the singers or song writers that they are sure the songs do not expose lust, profanity, violence, misogyny, drug and alcohol abuse, racist, and other bad things to be enjoyed by their children.

\section{CONCLUSION}

In conclusion, it could be stated that the 17 English songs mostly expose the propaganda of lust, profanity, and drug or alcohol abuse. Though insignificantly, however, they also expose violence, misogyny, and racist. It is for this reason that the Broadcasting Commission of West Java rescheduled the radio and television broadcasts of those songs that children may not be too much contaminated with the negative contents.

It is found out that the negative contents are mostly worded in clauses and communicated in such speech figures as periphrasis, simile, litotes, meiosis, and others. Because of the use of speech figures, the lyrics of the songs sound very beautiful. What is more, they are delivered with the melody of some musical instruments to make the song more enlivening and interesting. Such condition could hypnotize the song lovers or listeners that parents need to get involved themselves in accompanying their children in the song selection.

Another important fact about the data is that the songs are promoted by male singers and male-female duets in pop, $\mathrm{R}$ and $\mathrm{B}$, and hip hop music genres. Of course it is not meant to generalize but it is to describe the fact that people cannot be prejudiced with gender that promotes negative contents and music genre which exposes them. It is the content which is more important to focus if the government institution needs to ban or reschedule the radio and television broadcasts of certain songs.

The government must also redefine what is meant by negative content. This also becomes as important as redefining the policy of banning and rescheduling the radio and television broadcasts of certain songs that people may not claim that the government has exercised a power abuse and demolished human creativity. The government should also reconsider how to regulate the friendly access of videos or audios with negative contents provided by YouTube and Spotify.

\section{ACKNOWLEDGEMENT}

The authors would like to thank Dr. Sugeng Purwanto, MA and Unisbank academicians for their valuable comments and suggestions during the dissemination of the research findings. We also gratefully acknowledge funding provided by the University. 
Soepriatmadji, L., \& Rustipa, K. (2020). Some negative contents portrayed in English song lyrics. EduLite: Journal of English Education, Literature, and Culture, 5 (1), 148-158.

\section{REFERENCES}

Allegri, C. (2019). Malaysia bans 'Despacito 'on state broadcaster for offensive lyrics. $\quad$ Retrieved $\quad$ March 2019, from https://www.reuters.com/article/us-music-despacito-malaysiaidUSKBN1A513G

Anderson, C. A., Carnagey, N. L., \& Eubanks, J. (2003). Exposure to violent media: The effects of songs with violent lyrics on aggressive thoughts and feelings. 84(5), 960-971. https://doi.org/10.1037/0022-3514.84.5.960

Frisby, C. M. (2016). Undressing the words : prevalence of profanity, misogyny, violence, and gender role references in popular music. (August 2010).

Johnson, J. D., Adams, M. S., Ashburn, L., \& Reed, W. (1995). Differential gender effects of exposure to rap music on African American adolescents. Acceptance of teen dating violence. 33(1991), 597-598.

Jones, L. (2018). 'Baby, It's Cold Outside' is not an ode to rape - banning it is stupid. Retrieved March 19, 2019, from https://www.independent.co.uk/arts-entertainment/music/news/babyits-cold-outside-lyrics-dean-martin-ban-controversy-daughter-deanacriticism-reaction-a8678716.html.

Koreaboo. (2018). K-Pop is illegal in North Korea... But now it was allowed to be played in public for the first time. Retrieved March 19, 2019, from https://www.koreaboo.com/news/kpop-illegal-north-korea-now-allowedplayed-public-first-time/

Kusumaningsih, D., Santosa, R., \& Subroto, H. D. E. (2018). Vulgar and obscene terms in Indonesian song lyrics. 166(Prasasti), 60-65.

Lynxwiler, J., \& Gay, D. (2000). Moral boundaries and deviant music: public attitudes toward heavy metal and rap. 21(1), 63-85.

Madanikia, Y., \& Bartholomew, K. (2014). Themes of lust and love in popular music lyrics from 1971 to 2011. SAGE Open, 4(3), 2158244014547179.

Moernantyo, J. (2015). Pelecehan Seksual Dalam Lirik Lagu. (Yoyakarta).

Monson, I. (2000). The African diaspora: A Musical perspective (1st Ed.). New York: Garland Publishing, Inc.

Mutegi, J. W., Bannister, V. R. P., \& Nichols, B. H. (2014). Tales from the Mic: A content analysis of 10 years of hip-hop lyrics, urban center for the advancement of STEM Educ. (January 2016).

Nauert, R. (2018). VPN built into the browser song lyrics in uence sexual behavior free \& unlimited VPN by Opera.

Powell, C. T. (1991). Search education resources Rap Music: An Education with a beat from the street. 245-259.

Ramadhani, Y. (2019). Bruno Mars protes lagunya dibatasi jam Tayang di Jawa Barat. Retrieved March 19, 2019, from Tirto.id website: https://tirto.id/bruno-mars-protes-lagunya-dibatasi-jam-tayang-dijawa-barat-dhWQ 
Ramdhani, D. (2019). Ini alasan KPID Jabar batasi jam tayang 17 lagu berbahasa Inggris. Retrieved March 19, 2019, from Kompas.com website: https://regional.kompas.com/read/2019/02/27/12121911/ini-alasankpid-jabar-batasi-jam-tayang-17-lagu-berbahasa-inggris

Rideout, V. J., Foehr, U. G., \& Roberts, D. F. (2010). Generation M2 - Media in the Lives of 8- to 18-Year-Olds. California: The Henry J Kaiser Family Foundation.

Rudman, L. \& Lee, M. (2002). Group Processes \& Intergroup. 2002, 133-150. https://doi.org/10.1177/1368430202005002541

Samudro, A. (2019). Deretan negara yang keluarkan larangan \& pembatasan jam tayang lagu. Retrieved March 19, 2019, from Tirto.id website: https://www.independent.co.uk/arts-

entertainment/music/features/baby-its-cold-outside-lyrics-ban-rapedean-martin-lady-gaga-bette-midler-a8691641.html

Setiawan, R. (2019). KPID Jabar batasi siaran 17 lagu, PSI: Kriterianya Tidak jelas. Retrieved March 19, 2019, from Tirto.id website: https://tirto.id/kpid-jabar-batasi-siaran-17-lagu-psi-kriterianya-tidakjelas-dhVu

Susilo, W. (2019). Melarang lagu dalam sejarah politik Indonesia. Retrieved March 19, 2019, from Solopos.com website: https://img.solopos.com/thumb/posts/2019/03/15/978138/wahyususilo.jpg?w $=600 \& \mathrm{~h}=400$

Suwanto, I. (2016). Mengungkap data tentang perilaku penikmat musik di era digital. Retrieved from https://beritagar.id/artikel/sainstekno/mengungkap-data-tentang-perilaku-penikmat-musik-di-era-digital (24 Maret 2019)

Thompson, W. F., Geeves, A. M., \& Olsen, K. N. (2018). Who enjoys listening to violent music and why? Who Enjoys Listening to Violent Music and Why? (January). https://doi.org/10.1037/ppm0000184. 